University of Nebraska - Lincoln

DigitalCommons@University of Nebraska - Lincoln

1974

\title{
Breeding Waterfowl Populations in the Prairie Pothole Region of North Dakota
}

\author{
Robert E. Stewart \\ U.S. Bureau of Sport Fisheries and Wildlife \\ Harold A. Kantrud \\ U.S. Bureau of Sport Fisheries and Wildlife
}

Follow this and additional works at: https://digitalcommons.unl.edu/usgsnpwrc

Part of the Other International and Area Studies Commons

Stewart, Robert E. and Kantrud, Harold A., "Breeding Waterfowl Populations in the Prairie Pothole Region of North Dakota" (1974). USGS Northern Prairie Wildlife Research Center. 176.

https://digitalcommons.unl.edu/usgsnpwrc/176

This Article is brought to you for free and open access by the US Geological Survey at DigitalCommons@University of Nebraska - Lincoln. It has been accepted for inclusion in USGS Northern Prairie Wildlife Research Center by an authorized administrator of DigitalCommons@University of Nebraska - Lincoln. 


\section{BREEDING WATERFOWL POPULATIONS IN THE PRAIRIE POTHOLE REGION OF NORTH DAKOTA}

\section{ROBERT E. STEWART}

AND

\section{HAROLD A. KANTRUD}

U.S. Bureau of Sport Fisheries and Wildlife Northern Prairie Wildlife Research Center Jamestown, North Dakota 58401
The pothole areas within the glaciated, northern prairies and adjoining parklands of southcentral Canada and north-central United States are the principal breeding grounds for many species of North American ducks. Millions of pairs, including dabbling ducks (Anatinae) and diving ducks (Aythyinae and Oxyurinae), resort here for nesting each year. These populations are characterized by instability. In response to the variable climatic conditions of this region and their effect on wetland habitats, the numbers of breeding pairs often fluctuate greatly from year to year. In addition, regional populations are influenced by man. Factors that are especially important in this regard include the modification or destruction of wetlands due to intensive land-use practices, and variations in annual hunting pressure along the migration routes and wintering grounds.

Appropriate habitat management programs are essential for the pothole region if the numbers of breeding ducks are to be maintained at satisfactory levels. The development of such programs will require more reliable estimates of breeding populations and a better insight concerning their environmental relationships than have been available heretofore. The primary purpose of these investigations was to obtain reasonably accurate estimates of breeding waterfowl populations in the Prairie Pothole Region of North Dakota, and to determine the relationships of these populations to generalized wetland habitat conditions.

\section{THE STUDY AREA}

The Prairie Pothole Region of North Dakota was previously described and mapped in detail (Stewart and Kantrud 1972, 1973). This heavily glaciated prairie region occurs in the east-central and northwestern portions of the state and encompasses about 36,400 square miles, $51.5 \%$ of total state area (see fig. 1). It is characterized throughout by the presence of numerous shallow basin wetlands, and covers two distinctive physiographic areas that are referred to as the Drift Plain and Missouri Coteau. The re- gion is considered to contain four biotic sections, or subregions, that are designated as the Northeastern Drift Plain, Southern Drift Plain, Northwestern Drift Plain, and Missouri Coteau. Gently rolling ground moraine is the principal glacial landform of the Drift Plains, while the knob-and-kettle topography of dead-ice moraine is prevalent on the Missouri Coteau. Other glacial landforms, including end moraines, glacial outwash plains, lake plains, and deltaic sand dunes, occur locally in all sections.

The Prairie Pothole Region includes many different types of wetland habitat, including the major classes of natural basin wetlands (Stewart and Kantrud 1971), fluviatile wetlands, and man-made wetlands. Most of the natural basin wetlands are differentiated on the basis of degree of surface-water permanence and are categorized as: ephemeral (Class I) ponds; temporary (Class II) ponds; seasonal (Class III) ponds; semipermanent (Class IV) ponds and lakes; and permanent (Class V) ponds and lakes. Two other classes of minor importance include alkali ponds and lakes (Class VI) and fens (Class VII). Fluviatile wetlands include permanent and intermittent streams and their associated oxbows. Man-made wetlands are represented by the following: stock ponds; dugouts; large, shallow stream impoundments; reservoirs; road ditches; drainage channels; and sewage lagoons.

The relative importance of this region to breeding waterfowl is indicated by census data taken during a statewide random sampling study in 1967. That year it contained about $84 \%$ of the total breeding duck pairs in the state (Stewart and Kantrud 1973). The Prairie Pothole Region of North Dakota is contiguous with other prime waterfowl-producing areas that extend through the prairies and parklands of southern Alberta, southern Saskatchewan, southwestern Manitoba, northeastern Montana, western Minnesota, and eastern South Dakota.

\section{METHODS}

Field investigations were conducted throughout the Prairie Pothole Region of North Dakota during the waterfowl breeding seasons of 1967, 1968, and 1969 . Estimates of frequencies, population densities, and projected populations of breeding waterfowl were calculated from data obtained through use of stratified random sampling techniques. In addition, a survey of wetland habitat was completed in conjunction with the censuses of waterfowl. The fieldwork in 1967 and 1968 was conducted by the authors without assistants. In 1969 a cooperative program was instituted which involved the assistance of other federal and state biologists. 


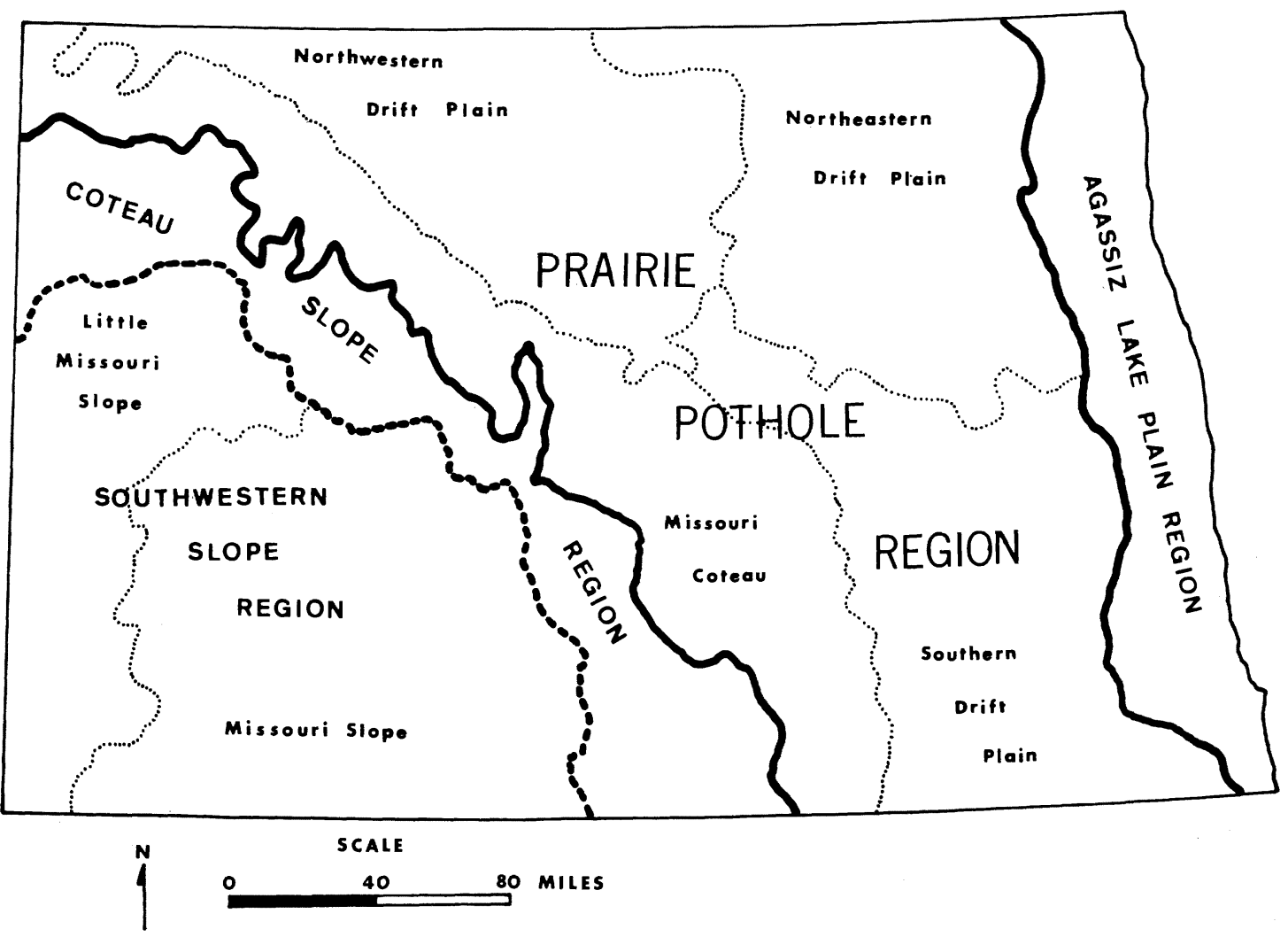

FIGURE 1. Biotic regions and subregions of North Dakota.

In 1967 these investigations were part of a statewide study that included censuses of all birds on upland as well as wetland habitats, and the published report (Stewart and Kantrud 1972) includes a description of the biotic stratification of the region, the random methods employed for selection of sample units, and the field techniques utilized in censusing waterfowl. The sample size and density and distribution of sample units were varied each year in an attempt to improve the estimates of waterfowl populations. Yearly adjustments in the dates of waterfowl censuses were also necessary due to the effects of variable weather conditions on the breeding period of each species of waterfowl. These modifications have been reported in detail (Stewart and Kantrud 1973).

The random sample units consisted of single, legal quarter sections ( 160 acres, or 0.5 mile $\times 0.5$ mile) during 1967 and 1968. The total sample in 1967 was composed of 68 units that were proportionally allocated as follows: Northeastern Drift Plain, 17; Southern Drift Plain, 18; Northwestern Drift Plain, 15; and Missouri Coteau, 18. In 1968 the sample contained 194 units, including 35 on the Northeastern Drift Plain, 42 on the Southern Drift Plain, 36 on the Northwestern Drift Plain, and 81 on the Missouri Coteau. A cluster sampling technique was utilized in 1969, each cluster consisting of four quarter sections that formed the corners of a square with dimensions of $2 \times 2$ miles. This sample contained 332 quarter sections, grouped as 83 clusters which were distributed as follows: 10 on the Northeastern Drift Plain; 23 on the Southern Drift Plain; 10 on the Northwestern Drift Plain; and 40 on the Missouri Coteau.
The analysis of census data involved the calculation of probability limits of means which are referred to as highest probability density (HPD) regions (Schmitt 1969). These regions, which are analogous to confidence intervals, were constructed utilizing the fact that the number of breeding pairs present cannot be negative. In tables below, nonoverlapping HPD regions indicate significant $(P<$ 0.05 ) differences in the frequencies and population densities of the various species. No attempt has been made to indicate significant differences that existed occasionally in cases where HPD regions overlapped slightly. Correlation coefficients were calculated to show relationships between waterfowl density estimates and habitat conditions over the 3-year study period.

\section{RESULTS}

\section{WETLANDS WITH SURFACE WATER}

The amount of annual and seasonal precipitation in the Prairie Pothole Region often varies greatly, resulting in alternating wet and dry periods. In response to these climatic changes, the numbers of wetlands containing surface water fluctuated considerably during the period of investigation (G. Pospichal and cooperators, unpubl. data). The frequency of occurrence, numbers, and acreage of wetlands containing surface water on the quarter-section sample units during the 3-year period are listed in table 1. In 1968, 
TABLE 1. Summary statistics of wetlands containing surface water in the Prairie Pothole Region of North Dakota, 1967-69. ${ }^{\text {a,b }}$

\begin{tabular}{|c|c|c|c|c|c|c|c|c|c|}
\hline \multirow[b]{2}{*}{ Habitat type } & \multicolumn{3}{|c|}{$\begin{array}{c}\text { Frequency } \\
\text { (\% of sample units) }\end{array}$} & \multicolumn{3}{|c|}{$\begin{array}{l}\text { Mean density } \\
\left(\text { no. per } \mathrm{mi}^{2}\right)^{\mathrm{c}}\end{array}$} & \multicolumn{3}{|c|}{$\begin{array}{c}\text { Mean area } \\
\left(\text { acres per } \mathrm{mi}^{2}\right)\end{array}$} \\
\hline & 1967 & 1968 & 1969 & 1967 & 1968 & 1969 & 1967 & 1968 & 1969 \\
\hline Untilled seasonal ponds (Class III) & 55.9 & 49.4 & 62.8 & 10.5 & 6.0 & 9.6 & 15.4 & 6.8 & 17.9 \\
\hline Semipermanent ponds and lakes (Class IV) & 17.6 & 25.8 & 30.3 & 1.0 & 1.7 & 2.2 & 11.6 & 6.3 & 13.9 \\
\hline 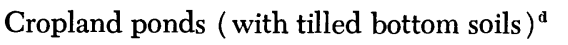 & 26.5 & 20.1 & 42.9 & 5.6 & 5.5 & 4.9 & 3.9 & 1.6 & 7.6 \\
\hline Streams and oxbows & 13.2 & 10.6 & 8.7 & 0.7 & 0.4 & 0.4 & 6.3 & 2.5 & 1.9 \\
\hline Man-made wetlands & 23.5 & 40.5 & 27.1 & 1.2 & 1.5 & 1.4 & 5.6 & 0.4 & 2.1 \\
\hline Total wetlands $\mathbf{e}^{\mathbf{e}}$ & 85.3 & 74.7 & 88.7 & 20.5 & 16.4 & 20.6 & 51.3 & 29.1 & 46.3 \\
\hline
\end{tabular}

a Wetland data collected during the following periods: 1967-14 May to 10 July; 1968 - 15 May to 15 July; $1969-20$ May to 10 June.

b Number of sample units censused each year were as follows: $1967-68 ; 1968-194 ; 1969-83$.

c Includes wetlands lying partially outside sample unit boundaries.

d Ponds with tilled bottom soils including temporary (Class II), seasonal (Class III), and undifferentiated Class II and III ponds.

- Includes: ephemeral (Class I) ponds; temporary (Class II) ponds with untilled bottom soils; permanent (Class V) ponds and lakes; alkali (Class VI) ponds and lakes; and fen (Class VII) ponds in addition to the other habitat types listed.

the frequency of occurrence and numbers of seasonal ponds with untilled bottom soils and total wetlands of all types were noticeably lower than in 1967 and 1969. An even greater disparity may be noted when acreages of wetlands with surface water are compared. In general, excellent water conditions were prevalent during the waterfowl breeding seasons of 1967 and 1969, while in 1968 fairly severe drought conditions were evident over a large portion of the area.

\section{FREQUENCY OF BREEDING WATERFOWL}

Information concerning frequency of occurrence of breeding waterfowl (table 2) is indicative of their distributional pattern as related to the availability of suitable habitat within the Prairie Pothole Region. This information also emphasizes the importance of the region to waterfowl since an average of $82 \%$ of the quarter-section sample units during the period 1967-69 were occupied by breeding pairs. Frequency of dabbling ducks was about four times greater than frequency of diving ducks. The five primary species of dabbling ducks, listed in order of decreasing average frequency, were the Mallard (Anas platyrhynchos), Pintail (A. acuta), Bluewinged Teal (A. discors), Gadwall (A. strepera), and Shoveler (A. clypeata). For these, average frequencies during the 3-year period ranged from a high of $65 \%$ to a low of $38 \%$. Among the diving ducks, Redheads (Aythya americana) and Ruddy Ducks (Oxyura jamaicensis) were encountered most often, with average frequencies of 14 and $9 \%$, respectively.

During the 3-year period, frequencies for total ducks, dabbling ducks as a group, and three species of dabblers-the Mallard, Pin-
TABLE 2. Frequency (per cent) of occurrence of breeding waterfowl per quarter section in the Prairie Pothole Region of North Dakota, 1967-69. ${ }^{\mathrm{a}}$

\begin{tabular}{llll}
\hline \hline 1967 & 1968 & 1969 & $\begin{array}{c}\text { 3-year } \\
\text { average }\end{array}$ \\
\hline
\end{tabular}

Primary species

$\begin{array}{lllll}\text { Mallard } & 81(71-89) & 52(45-59) & 61(53-68) & 65 \\ \text { Gadwall } & 50(38-62) & 38(32-45) & 58(48-70) & 49 \\ \text { Pintail } & 75(64-85) & 37(30-44) & 70(61-77) & 61 \\ \begin{array}{l}\text { Blue- } \\ \quad \text { winged }\end{array} & & & & \\ \quad \text { Teal } & 57(46-69) & 49(42-56) & 71(62-81) & 59 \\ \text { Shoveler } & 40(29-51) & 19(14-25) & 55(45-64) & 38\end{array}$

Secondary species

Green-

winged

Teal 31(21-42) 14( 9-19) 25(17-32) 23

American

Wigeon 16( 8-26) 10( 6-14) 16(11-21) 14

Redhead 12(5-20) 10(6-14) 20(15-25) 14

Ring-

necked

Duck 1( $0-6) \quad 3(1-5) \quad 4(1-8) \quad 3$

Canvas-

back $\quad 4(1-10) \quad 5(2-8) \quad 9(6-13) \quad 6$

Lesser

Scaup 3( $0-8) \quad 2(0-3) \quad 9(5-14) \quad 5$

Ruddy

$\begin{array}{lllll}\text { Duck } & 7(2-14) & 8(5-12) & 13(9-18) & 9\end{array}$

Total

dabbling

$\begin{array}{lllll}\text { ducks } & 91(84-97) & 70(64-77) & 86(78-93) \quad 82\end{array}$

Total

diving

ducks 19(11-29) 16(11-21) 29(23-35) 21

Total ducks

(all

species) $\quad 91(84-97) \quad 70(64-77) \quad 86(80-93) \quad 82$

a Figures shown in parentheses following frequencies in 1967, 1968, and 1969 represent 95\% HPD (highest probability density) regions. 
TABLE 3. Population densities (pairs per square mile) of breeding waterfowl in the Prairie Pothole Region of North Dakota, 1967-69. ${ }^{\mathrm{a}}$

\begin{tabular}{|c|c|c|c|c|}
\hline & 1967 & 1968 & 1969 & 3-year average \\
\hline \multicolumn{5}{|l|}{ Primary species } \\
\hline Mallard & $9.8(7.9-11.4)$ & $5.2(3.7-6.6)$ & $6.8(5.5-8.1)$ & 7.3 \\
\hline Gadwall & $5.6(2.7-8.5)$ & $3.7(2.7-4.8)$ & $5.4(4.3-6.4)$ & 4.9 \\
\hline Pintail & $8.4(6.5-10.2)$ & $3.1(2.3-3.8)$ & $10.4(8.3-12.5)$ & 7.3 \\
\hline Blue-winged Teal & $15.6(10.4-20.7)$ & $9.1(6.8-11.3)$ & $16.9(13.3-20.6)$ & 13.9 \\
\hline Shoveler & $4.3(2.2-6.5)$ & $1.4(0.9-1.9)$ & $5.8(4.5-7.1)$ & 3.8 \\
\hline \multicolumn{5}{|l|}{ Secondary species } \\
\hline Green-winged Teal & $2.7(1.5-3.9)$ & $0.8(0.5-1.1)$ & $2.1(1.3-2.8)$ & 1.8 \\
\hline American Wigeon & $1.2(0.3-2.1)$ & $0.4(0.2-0.6)$ & $0.9(0.6-1.3)$ & 0.9 \\
\hline Redhead & $1.7(0.0-3.3)$ & $1.5(0.7-2.4)$ & $2.0(1.4-2.6)$ & 1.8 \\
\hline Ring-necked Duck & $0.1(0.0-0.3)$ & $0.2(0.0-0.4)$ & $0.3(0.0-0.5)$ & 0.2 \\
\hline Canvasback & $0.7(0.0-1.6)$ & $0.5(0.1-0.8)$ & $0.7(0.2-1.1)$ & 0.6 \\
\hline Lesser Scaup & $0.1(0.0-0.2)$ & $0.1(0.0-0.3)$ & $0.9(0.4-1.4)$ & 0.4 \\
\hline Ruddy Duck & $2.2(0.0-4.3)$ & $1.3(0.5-2.2)$ & $1.6(0.9-2.3)$ & 1.7 \\
\hline Total dabbling ducks ${ }^{\mathbf{b}}$ & $47.6(35.6-59.6)$ & $23.7(18.7-28.6)$ & $48.3(40.1-56.5)$ & 39.8 \\
\hline Total diving ducks & $4.8(1.2-8.4)$ & $3.7(1.9-5.5)$ & $5.4(3.6-7.3)$ & 4.6 \\
\hline $\begin{array}{l}\text { Total ducks } \\
\quad(\text { all species })^{b}\end{array}$ & $52.4(37.0-67.9)$ & $27.4(21.1-33.6)$ & $53.7(44.5-62.9)$ & 44.5 \\
\hline
\end{tabular}

a Figures shown in parentheses following densities in 1967,1968 and 1969 represent 95\% HPD regions.

b Total dabbling ducks and total ducks include very small, insignificant densities of the Cinnamon Teal (Anas cyanoptera) and Wood Duck (Aix sponsa) in addition to the species listed.

tail, and Green-winged Teal (Anas crecca)were highest in 1967. In contrast, lowest frequencies were recorded in 1968 for total ducks, for all species of dabbling ducks, for diving ducks as a group, and for two species of diving ducks-the Redhead and Lesser Scaup (Aythya affinis). From 1968 to 1969, frequencies of all species showed an increase; peak frequencies were attained in 1969 for all diving duck species and for the Gadwall, Blue-winged Teal, and Shoveler.

Comparisons of proportional frequency changes among the species indicated that the Mallard, Gadwall, Blue-winged Teal, and American Wigeon (Anas americana) were comparatively stable. The fluctuations exhibited by the Pintail, Green-winged Teal, Shoveler, Ring-necked Duck (Aythya collaris), and Lesser Scaup were much more pronounced, while the Redhead, Canvasback (Aythya valisineria), and Ruddy Duck were somewhat intermediate in this regard.

\section{POPULATIONS OF BREEDING WATERFOWL}

Population parameters that were calculated for breeding waterfowl in the Prairie Pothole Region during 1967-69 include population densities (table 3 ) and projected populations (table 4). The average density of total ducks per square mile was 44.5 pairs, including 39.8 pairs of dabbling ducks and 4.6 pairs of diving ducks. Average projected populations based on these density figures were calculated as $1,619,000$ pairs of total ducks, including $1,450,000$ pairs of dabbling ducks and 169,000 pairs of diving ducks.

Average population densities, ranging from 3.8 to 13.9 pairs per square mile, and average projected populations, ranging from 140,000 to 504,000 pairs, were calculated for the five primary species. These species listed in order of increasing abundance were: Shoveler, Gadwall, Mallard, Pintail, and Blue-winged Teal. Medium densities and projected populations of appreciable importance were recorded for the Green-winged Teal, Redhead, and Ruddy Duck. The densities and populations for the American Wigeon, Ring-necked Duck, Canvasback, and Lesser Scaup were comparatively low. Several breeding species of minor importance in the region, including the Cinnamon Teal (Anas cyanoptera), Wood Duck (Aix sponsa), Common Goldeneye (Bucephala clangula), Bufflehead (Bucephala albeola), and Hooded Merganser (Lophodytes cucullatus), were either unrecorded on the sample units or were represented by very small, insignificant numbers.

Yearly variations in population densities and in projected populations were very pronounced, particularly for total ducks, total dabbling ducks, and for the following species: 
TABLE 4. Population estimates (number of pairs) of breeding waterfowl in the Prairie Pothole Region of North Dakota, 1967-69. ${ }^{\mathrm{a}}$

\begin{tabular}{|c|c|c|c|c|}
\hline & 1967 & 1968 & 1969 & 3 -year average ${ }^{b}$ \\
\hline \multicolumn{5}{|l|}{ Primary species } \\
\hline Mallard & 357,000 & 188,000 & 247,000 & $264,000(16.3 \%)$ \\
\hline Gadwall & 203,000 & 136,000 & 195,000 & $178,000(11.0 \%)$ \\
\hline Pintail & 304,000 & 111,000 & 379,000 & $265,000(16.4 \%)$ \\
\hline Blue-winged Teal & 566,000 & 330,000 & 616,000 & $504,000(31.1 \%)$ \\
\hline Shoveler & 158,000 & 51,000 & 211,000 & $140,000(8.6 \%)$ \\
\hline \multicolumn{5}{|l|}{ Secondary species } \\
\hline Green-winged Teal & 98,000 & 28,000 & 76,000 & $67,000(4.1 \%)$ \\
\hline American Wigeon & 44,000 & 15,000 & 34,000 & $31,000(1.9 \%)$ \\
\hline Redhead & 63,000 & 56,000 & 72,000 & $64,000(4.0 \%)$ \\
\hline Ring-necked Duck & 4,000 & 7,000 & 10,000 & $7,000(0.4 \%)$ \\
\hline Canvasback & 24,000 & 17,000 & 25,000 & $22,000(1.4 \%)$ \\
\hline Lesser Scaup & 4,000 & 5,000 & 32,000 & $14,000(0.9 \%)$ \\
\hline Ruddy Duck & 79,000 & 49,000 & 58,000 & $62,000(3.8 \%)$ \\
\hline Total dabbling ducks ${ }^{\mathrm{c}}$ & $1,732,000$ & 861,000 & $1,758,000$ & $1,450,000(89.6 \%)$ \\
\hline Total diving ducks & 175,000 & 134,000 & 198,000 & $169,000(10.4 \%)$ \\
\hline Total ducks (all species) ${ }^{\mathrm{c}}$ & $1,907,000$ & 995,000 & $1,955,000$ & $1,619,000(100.0 \%)$ \\
\hline
\end{tabular}

Pintail, Green-winged Teal, Shoveler, and American Wigeon. For these species and groups of species, the similar densities and populations in 1967 and 1969 were about twice as high as the densities and populations recorded in 1968. More stable populations were recorded for total diving ducks and for several other species of ducks, although a reduction of lesser magnitude also occurred in 1968. These other species included the Mallard, Gadwall, Blue-winged Teal, Redhead, Canvasback, and Ruddy Duck. Distinct, somewhat unique patterns of density and population change were recorded for the Ring-necked Duck and Lesser Scaup. The low populations of the Ring-necked Duck exhibited a gradual increase during the 3-year period, while the Lesser Scaup was represented by very low populations in 1967 and 1968, followed by an abrupt increase of major proportions in 1969.

Prior to our investigations, the only comparable survey of breeding waterfowl populations in North Dakota was conducted by M. C. Hammond (unpubl. data) in 1965 . His data, derived from intensive ground counts along 59 randomly selected 8-mile transects, indicated a breeding duck population density of 35.0 pairs per square mile in the Prairie Pothole Region of the state. This figure may be compared with our densities of $52.4,27.4$, and 53.7 pairs per square mile for the years 1967, 1968, and 1969, respectively.

During the 3-year period 1967-69, the trend in variation of breeding duck population densities, calculated from our census data, compared favorably with the index values of 38.1, 21.3, and 40.9 pairs per square mile that were obtained for the North Dakota Prairie Pothole Region from aerial survey data adjusted for visibility (G. Pospichal, pers. comm.). Breeding waterfowl censuses conducted from automobiles along roadside transects that were selected systematically throughout the state during the period 1948-70 indicated a fivefold difference between minimum and maximum annual populations that were recorded (Schroeder 1971).

The average composition of breeding waterfowl populations (table 4) consisted of $89.6 \%$ dabbling ducks and $10.4 \%$ diving ducks. The small variations in composition from year to year were shown by the proportions of dabbling ducks: $90.8 \%$ in $1967,86.5 \%$ in 1968 , and $89.9 \%$ in 1969 . The average population was composed roughly of $1 / 3$ Blue-winged Teal, $1 / 3$ Mallard and Pintail in combination, and $1 / 3$ all other species in combination. The Pintail and Shoveler were the primary species exhibiting the greatest fluctuations in their representative proportion of the total 
BREEDING WATERFOWL POPULATIONS IN PRAIRIE POTHOLES

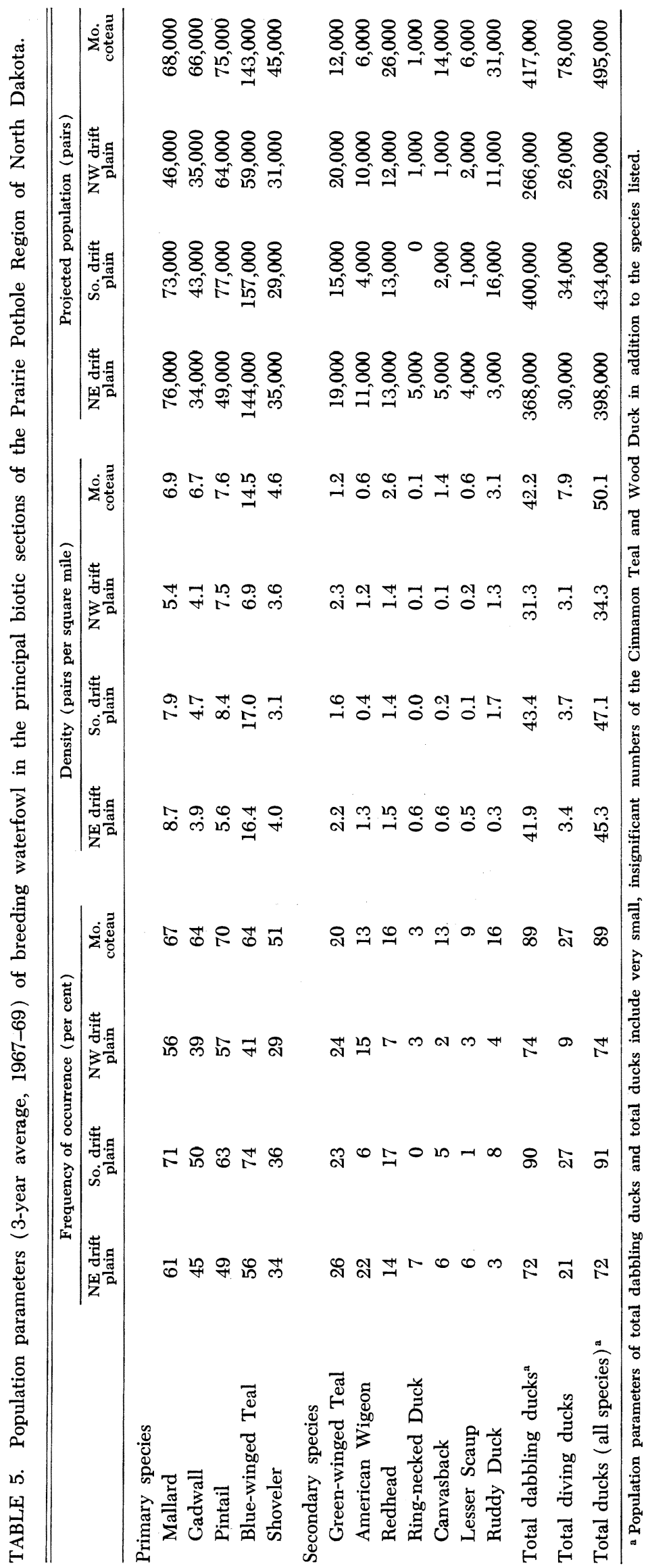


duck population during the 3-year period. In contrast, the proportion of Gadwall and Bluewinged Teal changed only slightly each year.

\section{SECTIONAL VARIATIONS IN BREEDING WATERFOWL POPULATIONS}

Relative proportions of breeding waterfowl in the four biotic sections or subregions of the Prairie Pothole Region were somewhat variable (table 5 ). One parameter of significance involved frequencies of occurrence. These values for total ducks and for dabbling ducks as a group were noticeably higher on the Southern Drift Plain and Missouri Coteau than on the Northeastern and Northwestern Drift Plains. For diving ducks as a group, frequencies were quite comparable on the Northeastern and Southern Drift Plains and Missouri Coteau, but were greatly reduced on the Northwestern Drift Plain.

Frequencies among the various species of ducks in the four biotic sections were relatively constant for the Mallard and Greenwinged Teal; quite variable for the American Wigeon and diving duck species; and intermediate in this respect for the Gadwall, Pintail, Blue-winged Teal, and Shoveler. Especially high frequencies were recorded on the Northeastern Drift Plain for the American Wigeon and Ring-necked Duck; on the Southern Drift Plain for the Blue-winged Teal; and on the Missouri Coteau for the Gadwall, Shoveler, Canvasback, and Ruddy Duck. Conversely, rather low frequencies were recorded on the Northeastern Drift Plain for the Pintail; on the Southern Drift Plain for the American Wigeon, Ring-necked Duck, and Lesser Scaup; and on the Northwestern Drift Plain for the Gadwall, Bluewinged Teal, Shoveler, Redhead, Canvasback, and Ruddy Duck.

On the basis of population densities and projected populations (table 5 ), the primary breeding grounds of ducks, especially dabbling ducks, were on the Northeastern and Southern Drift Plains and on the Missouri Coteau; the secondary breeding grounds were on the Northwestern Drift Plain. The highest density and projected population of diving ducks occurred on the Missouri Coteau; these figures were more than twice the corresponding values for the Northeastern, Southern, and Northwestern Drift Plains. The larger densities and projected populations for several species occurred on the Missouri Coteau. These species included the Gadwall, Shoveler, Redhead, Canvasback, and Ruddy Duck. The Mallard and Blue-winged Teal were repre- sented by fairly large, rather evenly distributed concentrations on the Northeastern and Southern Drift Plains and Missouri Coteau, while only relatively small numbers were present on the Northwestern Drift Plain. Pintails, on the other hand, were well represented on the Southern and Northwestern Drift Plains and Missouri Coteau, but only moderate numbers were found on the Northeastern Drift Plain. Other figures of interest include the rather evenly distributed populations of the Green-winged Teal, the relatively high populations of the American Wigeon on the Northeastern and Northwestern Drift Plains, and the relatively high population of Ringnecked Ducks and relatively low population of Ruddy Ducks on the Northeastern Drift Plain.

\section{RELATIONSHIPS OF POPULATIONS OF BREEDING WATERFOWL TO WET- LAND HABITAT}

In North Dakota during the period 1960-72, a highly significant correlation $(r=0.903, P<$ 0.01 ) existed between indices of total breeding duck populations and indices of the number of potholes containing surface water in May (G. Pospichal and cooperators, unpubl. data). The waterfowl population indices in this report were calculated from aerial survey data that were adjusted for visibility variables. In addition, during 1959-71, counts of breeding waterfowl and of basin wetlands containing surface water were conducted from automobiles along north-south roadside transects that were selected systematically throughout the state (Schroeder 1971). Analyses of these data also revealed a highly significant correlation $(r=0.904, P<0.01)$ between waterfowl populations and numbers of wetlands with surface water.

Population dynamics of breeding waterfowl have been investigated on the ground on numerous small block study areas or transects that were selected within the northern glaciated prairies and aspen parklands of Canada and the United States. In addition, aerial surveys of breeding waterfowl populations and wetland habitat have been conducted along east-west transects throughout the prairies and parklands. Many of these studies also indicated a positive correlation between numbers of wetlands with surface water and populations of breeding waterfowl. These correlations have been reported to occur in Alberta (Smith 1969, and 1971), in Alberta and Saskatchewan (Smith 1970), in Saskatchewan (Stoudt 1969, 1971), in Manitoba (Rogers 1964), in North Dakota (Salyer 1962), and in 
BREEDING WATERFOWL POPULATIONS IN PRAIRIE POTHOLES 77

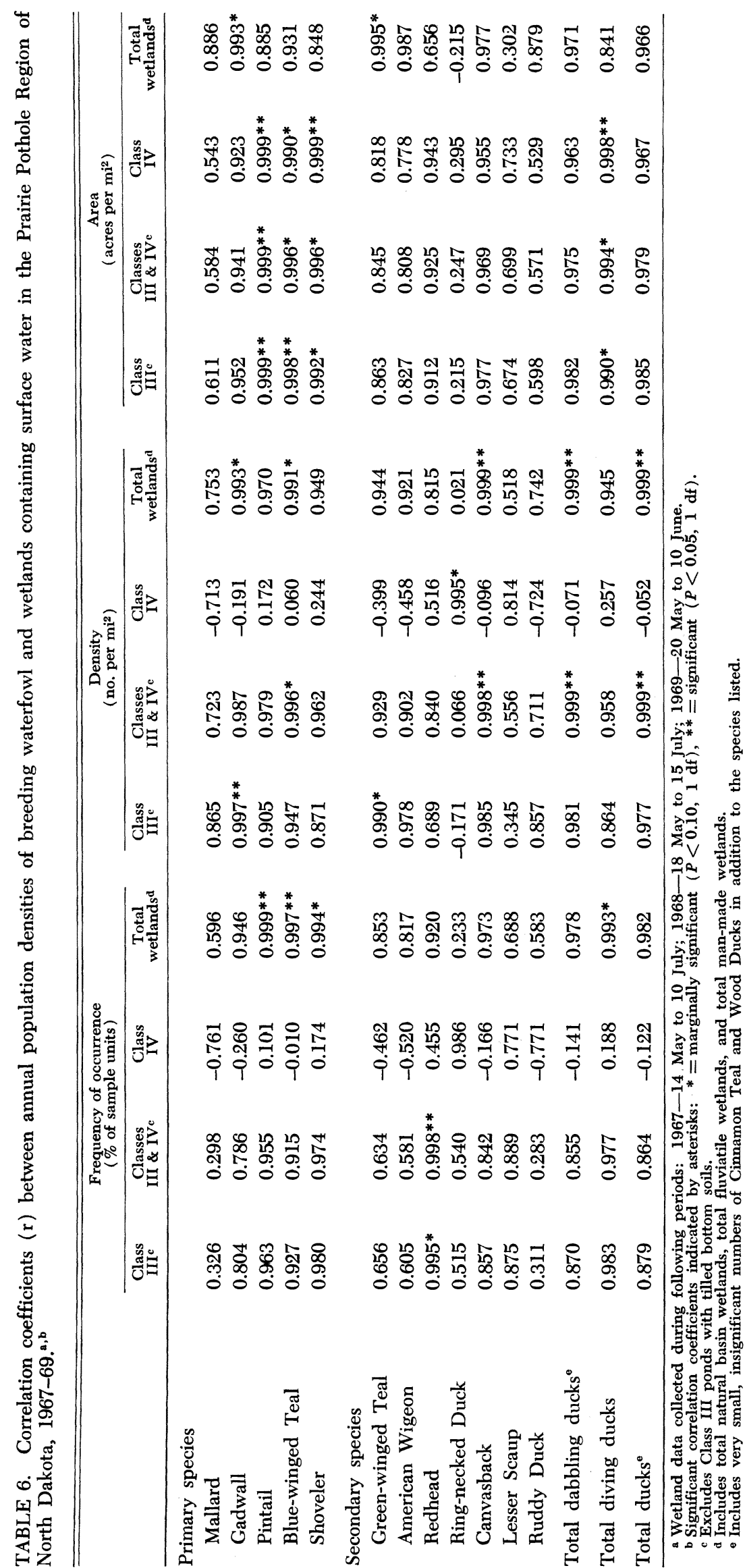


South Dakota (Drewien and Springer 1969; Evans and Black 1956; Jenni 1956).

The more pertinent information available regarding the interrelationships between wetland densities and breeding waterfowl populations was discussed in detail by Dzubin $(1969 \mathrm{a}, \mathrm{b})$. On the basis of his summarization, he recommended that correlations between waterfowl and wetlands should be determined for individual species only. $\mathrm{He}$ also suggested that these correlations would be more meaningful if populations were related to more specific categories of basin wetlands rather than to wetlands in toto.

Correlation coefficients between population densities of breeding waterfowl and the frequency, density, and area of the more important wetland habitats utilized by breeding waterfowl are shown in table 6. Many significant correlations occur although degrees of difference between correlations have not been tested statistically. Populations of total ducks and total dabbling ducks exhibited highest correlations with densities of Class III and IV wetlands in combination and with densities of total wetlands (table 6). Population fluctuations of total diving ducks were most closely related to changes in acreage of Class IV wetlands.

Significant correlations with wetlands were found for all primary species of ducks except the heavily hunted Mallard. Following the return of improved water conditions in 1969, the Mallard population did not increase proportionally as much as the other primary species (table 4). As pointed out by Dzubin (1969a), hunting mortality may decimate a population homing to a relatively large breeding area, resulting in an underpopulation even though optimum habitat conditions exist. Gadwall populations were most closely related to the density of Class III wetlands although marginally significant correlations also existed between numbers of Gadwalls and both density and area of total wetlands. Fluctuations in Pintail populations closely paralleled changes in acreage of Class III and IV wetlands, and a significant correlation was also found between numbers of Pintails and frequency of total wetlands. Yearly variations in populations of Blue-winged Teal and Shovelers were closely associated with fluctuations in area of Class III and Class IV wetlands, respectively.

Since mean population density estimates for the secondary species were less precise (table 3), a greater proportion of the significant correlation coefficients found for these species may have occurred due to chance. The highest correlation for Green-winged Teal was with total wetland area. Numbers of Redheads appeared to be related more closely to frequency of Class III and Class IV wetlands in combination, while annual fluctuations in Canvasback and Ring-necked Duck populations were associated mostly with changes in wetland density. No significant correlations were found between wetland habitat and variations among the American Wigeon, Lesser Scaup, and Ruddy Duck populations.

\section{SUMMARY}

Populations of breeding waterfowl in the Prairie Pothole Region of North Dakota were censused from 1967 to 1969 through use of random sampling techniques. These populations fluctuated considerably due primarily to yearly variations in frequency, density, and area of basin wetlands with surface water.

Average population parameters for total breeding ducks included a frequency of $82 \%$ on the quarter-section sample units, and a density of 44.5 pairs per square mile. The average projected population for the entire region was $1,619,000$ pairs, including $1,450,000$ pairs $(89.6 \%)$ of dabbling ducks, and 169,000 pairs $(10.4 \%)$ of diving ducks. Five primary species of ducks-the Mallard, Gadwall, Pintail, Blue-winged Teal, and Shovelercomprised $83 \%$ of the total breeding duck population. The Mallard exhibited the highest average frequency (65\%) and the Bluewinged Teal the highest average density (13.9 pairs per square mile).

Certain disparities in proportion of the breeding duck populations occurred in four biotic sections within the region. Population densities of total ducks and total dabbling ducks were fairly constant on the Northeastern and Southern Drift Plains and Missouri Coteau, but were noticeably lower on the Northwestern Drift Plain. The population density of total diving ducks was markedly higher on the Missouri Coteau than on the other three sections.

During the period 1967-69, significant correlations occurred between fluctuations of the total breeding waterfowl populations and variations in the number of wetland basins containing surface water. Populations of dabbling ducks as a group showed high correlations with densities of wetlands of all types, and equally high correlations with densities of seasonal (Class III) and semipermanent (Class IV) basin wetlands, in combination. 
Population fluctuations of total diving ducks were more closely related to changes in acreage of semipermanent (Class IV) ponds and lakes.

\section{ACKNOWLEDGMENTS}

Grateful acknowledgment is made to D. Alan Davenport for processing data from this study through the development and use of computer programs. A special thanks is due Douglas $H$. Johnson for his advice concerning the statistical analysis of these data. We also wish to thank the personnel (34 in number) from the U.S. Bureau of Sport Fisheries and Wildlife, U.S. Soil Conservation Service, and North Dakota Game and Fish Department for their assistance with the waterfowl censuses during 1969

\section{LITERATURE CITED}

Drewien, R. C., ANd P. F. Springer. 1969. Ecological relationships of breeding Blue-winged Teal to prairie potholes, p. 102-115. In Saskatoon Wetlands Seminar. Can. Wildl. Serv. Rept. Ser. no. 6.

Dzubin, A. 1969a. Comments on carrying capacity of small ponds for ducks and possible effect: of density on Mallard production, p. 138-160. In Saskatoon Wetlands Seminar. Can. Wildl. Serv. Rept. Ser. no. 6.

DzuBin, A. 1969b. Assessing breeding populations of ducks by ground counts, p. 178-230. In Saskatoon Wetlands Seminar. Can. Wildl. Serv. Rept. Ser. no. 6.

Evans, C. D., ANd K. E. Black. 1956. Duck production studies on the prairie potholes of South Dakota. U.S. Dept. Interior, Bur. Sport Fish. Wildl. Spec. Sci. Rept. Wildl. 32, 59 p.

Jenni, D. A. 1956. Pothole water levels in relation to waterfowl breeding populations and production. M.S. thesis, Utah St. Univ., Logan.

$\rightarrow$ Rogers, J. P. 1964. Effect of drought on reproduction of the Lesser Scaup. J. Wildl. Mgmt. 28:213-222.
SAlyer, J. W. 1962. Effects of drought and land use on prairie nesting ducks. Trans. 27th N. Amer. Wildl. Nat. Res. Conf., p. 69-79.

SchmitT, S. A. 1969. Measuring uncertainty: An elementary introduction to Bayesian statistics. Addison-Wesley, Reading, Mass.

SCHROEDER, C. H. 1971. Breeding ground survey in North Dakota in 1971. North Dakota State Game and Fish Dept. Job Rept. P-R Project W-67-R-11, Phase D, J-4, 8 p. (processed).

SмIтн, A. G. 1969. Waterfowl-habitat relationships on the Lousana, Alberta, waterfowl study area, p. 116-122. In Saskatoon Wetlands Seminar. Can. Wildl. Serv. Rept. Ser. no. 6.

Sмiтн, A. G. 1971. Ecological factors affecting waterfowl production in the Alberta parklands. U.S. Dept. Interior, Bur. Sport Fish. Wildl. Res. Publ. 98, 49 p.

$\rightarrow$ SMrth, R. I. 1970. Response of Pintail breeding populations to drought. J. Wildl. Mgmt. 34:943946.

Stewart, R. E., and H. A. Kantrud. 1971. Classification of natural ponds and lakes in the glaciated prairie region. U.S. Dept. Interior, Bur. Sport Fish. Wildl. Res. Publ. 92, 57 p.

Stewart, R. E., and H. A. Kantrud. 1972. Population estimates of breeding birds in North Dakota. Auk 89:766-788.

$\rightarrow$ Stewart, R. E., ANd H. A. Kantrud. 1973. Ecological distribution of breeding waterfowl populations in North Dakota. J. Wildl. Mgmt. 37:3950 .

Stoudr, J. H. 1969. Relationship between waterfowl and water areas on the Redvers waterfowl study area, p. 123-131. In Saskatoon Wetlands Seminar. Can. Wildl. Serv. Rept. Ser. no. 6.

Stoudt, J. H. 1971. Ecological factors affecting waterfowl production in the Saskatchewan parklands. U.S. Dept. Interior, Bur. Sport Fish. Wildl. Res. Publ. 99, 58 p.

Accepted for publication 14 May 1973. 